\title{
Modified Silica Nanoparticles with an Aminonaphthoquinone
}

\author{
Gleiciani Q. Silveira, ${ }^{a}$ Célia M. Ronconi, ${ }^{* a}$ Maria D. Vargas, ${ }^{*, a}$ Rosane A. S. San Gil ${ }^{b}$ \\ and Alvicler Magalhães ${ }^{c, d}$
}

\author{
anstituto de Química, Universidade Federal Fluminense, Campus do Valonguinho, \\ Centro, 24020-150 Niterói-RJ, Brazil \\ ${ }^{b}$ Instituto de Química, Universidade Federal do Rio de Janeiro, Ilha do Fundão, \\ 21945-970 Rio de Janeiro-RJ, Brazil
}

'Instituto Oswaldo Cruz, FIOCRUZ, CP 926, 21045-900 Rio de Janeiro-RJ, Brazil

${ }^{d}$ Instituto de Química, Universidade Estadual de Campinas, CP 6154, 13083-970 Campinas-SP, Brazil

\begin{abstract}
Nanopartículas de sílica (NPs) modificadas covalentemente com uma aminonaftoquinona foram sintetizadas e caracterizadas. A aminopropilsilicagelnaftoquinona (APSGNQ) foi obtida por substituição nucleofílica do grupo metóxi da 2-metóxi-1,4-naftoquinona por NPs modificadas com o grupo aminopropil (APSG). Os espectros de ressonância magnética nuclear de ${ }^{13} \mathrm{Ce}^{29} \mathrm{Si}$ no estado sólido confirmaram que a naftoquinona encontra-se ligada covalentemente à aminopropilsilicagel. Como o composto APSGNQ é solúvel em solventes orgânicos comuns, foi possível quantificar o ancoramento da naftoquinona na superfície das NPs modificadas por espectroscopia no ultravioletavisível (0,56 mmol de naftoquinona ancorada por grama de APSGNQ), por comparação com o espectro do composto análogo 2-aminobutil-1,4-naftoquinona (ABNQ). Os dados das análises elementares indicaram que aproximadamente $8 \%$ da propilamina presente na superfície do composto APSGNQ não reagiu com a metóxinaftoquinona. Essas NPs de sílica multifuncionais têm potencial para aplicações médicas.
\end{abstract}

The synthesis and characterization of silica nanoparticles (NPs) covalently modified with an aminonaphthoquinone are reported. The aminopropylsilicagelnaphthoquinone (APSGNQ) was obtained by nucleophilic substitution of 2-methoxy-1,4-naphthoquinone with aminopropylsilicalgel (APSG) NPs. Solid state ${ }^{13} \mathrm{C}$ and ${ }^{29} \mathrm{Si}$ nuclear magnetic resonance spectra confirmed that the naphthoquinone is covalently bonded to APSG. Due to the solubility of APSGNQ in common organic solvents, solution ultraviolet-visible spectroscopy was used to determine the amount of naphthoquinone on the NPs surface $(0.56 \mathrm{mmol}$ of incorporated naphthoquinone per gram of APSGNQ) by comparison with the spectrum of 2-aminobutyl-1,4-naphthoquinone (ABNQ). Elemental analysis indicated that about $8 \%$ of the surface propylamine remained unreacted in APSGNQ. These multifunctional silica NPs have potential in medical applications.

Keywords: multifunctional material, silica nanoparticles, naphthoquinones, solid state ${ }^{13} \mathrm{C}$ and ${ }^{29} \mathrm{Si}$ NMR

\section{Introduction}

Silica nanoparticles (NPs) modified with organic groups have been studied extensively. ${ }^{1-3}$ A large number of silanes carrying different organic functional groups have been used for the silica NPs surface modification, ${ }^{4}$ e.g., 3 -aminopropyltriethoxysilane ${ }^{2}$ and

*e-mail: mdvargas@vm.uff.br, cmronconi@vm.uff.br 3-iodopropyltrimethoxysilane. ${ }^{3,5}$ Amorphous silica NPs present high thermal and chemical stability and high surface area, which allows a variety of interactions with other materials. ${ }^{6}$ The modified compounds differ significantly from the original matrix and may have various technological applications, such as support for drug delivery, ${ }^{7}$ biosensors, ${ }^{8}$ biomarkers, ${ }^{9}$ magnetic devices, ${ }^{7}$ fabrication of electric and thermal insulators ${ }^{10}$ and in photodynamic therapy, ${ }^{11}$ among others. Organically modified silica NPs are particularly 
interesting for medical applications because they present low toxicity, ${ }^{12}$ are biocompatible ${ }^{12,13}$ and can be excreted in the urine. ${ }^{14}$

The work described herein involves the modification of silica NPs surface with 3-aminopropyltriethoxysilane for the incorporation of naphthoquinones. This class of compounds exhibits a wide range of biological properties, e.g. bactericide, ${ }^{15}$ fungicide, ${ }^{16}$ trypanocidal,${ }^{17}$ antimalarial, ${ }^{18}$ antileishmanial, ${ }^{18}$ anticancer, ${ }^{19,20}$ antitubercular ${ }^{21}$ and against Aedes aegypti. ${ }^{22}$ These biological activities have been associated to the interference of quinones in the electron transport chain by electron reduction processes, generating semiquinone radical $\left(\mathrm{Q}^{\bullet}\right)$ and hydroquinone anion $\left(\mathrm{Q}^{2-}\right){ }^{23}$ The presence of amino groups has been shown to potentiate some of these biological activities..$^{20,24}$

Herein we describe the successful anchoring of an aminonaphthoquinone on silica NPs. To the best of our knowledge, NPs containing covalently-bound naphtoquinones have not yet been reported in the literature.

\section{Experimental}

\section{Materials and methods}

The silica nanoparticles (NPs) (Aldrich, $15 \mathrm{~nm}, 637238$ ) were pretreated under high vacuum at $180^{\circ} \mathrm{C}$ for $10 \mathrm{~h}$ to remove adsorbed water. 3-Aminopropyltriethoxysilane and butylamine, both from Aldrich, were used without prior treatment. Toluene (Vetec) was previously dried with sodium/benzophenone under argon; methanol and ethanol were used as received. 2-(3-Butylamino)-1,4naphthoquinone $\mathrm{e}^{25}$ and 2-methoxy-1,4-naphthoquinone ${ }^{26}$ were prepared according to the literature. Transmission infrared (IR) spectra were obtained from $\mathrm{KBr}$ pellets with a FTIR Spectrum One (Perkin Elmer) spectrophotometer. IR diffuse reflectance (DRIFT) spectra were obtained with a FTIR Spectrum One (Perkin Elmer) spectrometer coupled to: $i$ ) a Praying Mantis Harrick, which consists of a domo of three windows (two $\mathrm{KBr}$ and a quartz) that protects the sample, ii) a Harrick Scientific ATC-124 model temperature controller and iii) a Matheson 8270 model argon flow controller $\left(30 \mathrm{~cm}^{3} \mathrm{~min}^{-1}\right)$. Thermogravimetric analyses were conducted with a Netzsch STA 409 PC TG/DTA equipment. Approximately $10 \mathrm{mg}$ of sample were weighed in an alumina crucible and heated at $35-1100{ }^{\circ} \mathrm{C}$, at the heating rate of $5{ }^{\circ} \mathrm{C} \mathrm{min}{ }^{-1}$, under nitrogen flow $\left(30 \mathrm{~cm}^{3} \mathrm{~min}^{-1}\right)$. Elemental analyses were carried out at the Central Analítica of the Instituto de Química, Universidade de São Paulo, Brazil. Solid-state ${ }^{13} \mathrm{C}$ and ${ }^{29} \mathrm{Si}$ NMR experiments were performed on a Bruker DRX300 spectrometer (7.05 T), operating at Larmor frequencies of 75.4 and $59.3 \mathrm{MHz}$ respectively and equipped with a $4 \mathrm{~mm}$ Bruker CPMAS probe and $\mathrm{ZrO}_{2}$ rotors, spinning at $6 \mathrm{kHz}\left({ }^{13} \mathrm{C}\right)$ and $5 \mathrm{kHz}$ $\left.{ }^{(29} \mathrm{Si}\right)$. For ${ }^{13} \mathrm{C}$ NMR spectra, the ${ }^{1} \mathrm{H}-{ }^{13} \mathrm{C}$ cross polarisation magic angle spinning (CPMAS) pulse sequence was employed, with optimised contact time of $2 \mathrm{~ms}$ and a repetition time (D1) of $4 \mathrm{~s} .{ }^{29} \mathrm{Si}$ MAS NMR spectra were acquired by using both ${ }^{1} \mathrm{H}^{-29} \mathrm{Si}$ cross polarisation (CPMAS) with contact time of $4 \mathrm{~ms}^{27}$ and direct polarisation with high power ${ }^{1} \mathrm{H}$ dipolar decoupling (HPDD) pulse sequences. In this case experiments were performed by using repetition times from 10 to $300 \mathrm{~s}$ based on literature data for similar samples. ${ }^{28}$ The results obtained with commercial silica NPs indicated that the repetition time of $60 \mathrm{~s}$ could be used to obtain quantitative Si spectra with enough signal-to-noise ratio to integrate the spectra. The external references used for the chemical shifts were the $\mathrm{CH}_{3}$ signal of hexamethylbenzene at $17.3 \mathrm{ppm}$ for ${ }^{13} \mathrm{C}$ and the $\mathrm{Q}^{3} \mathrm{Si}$ sites of caulinite at $-91.5 \mathrm{ppm}$ for ${ }^{29} \mathrm{Si}$. UV-Vis spectra were obtained with a diode array 8452A (Hewlett Packard - HP) spectrophotometer in spectroscopic grade dimethylsulfoxide (dmso).

Synthesis of the silica nanoparticles modified with aminopropyl groups (APSG) and functionalized with naphthoquinone groups (APSGNQ)

The reaction is illustrated in Scheme 1. Modification of the NPs surface with the aminopropyl group ${ }^{2}$ was carried out by addition of 3-aminopropyltriethoxysilane (APTES) (3 g, $13.5 \mathrm{mmol}$ ) to a suspension of silica NPs ( $3 \mathrm{~g})$ in refluxing toluene $(50.0 \mathrm{~mL})$ under stirring and argon atmosphere. After $1.5 \mathrm{~h}$, a small ethanol-containing toluene fraction was distilled off and more 3-aminopropyltriethoxysilane $(1.05 \mathrm{~g}, 4.78 \mathrm{mmol})$ was added to the toluene suspension. This procedure was repeated 3 times. After the reaction mixture was cooled down to room temperature, the white solid was filtered off and washed copiously in a Soxhlet apparatus with $\mathrm{CH}_{2} \mathrm{Cl}_{2}(500 \mathrm{~mL})$ and acetone $(500 \mathrm{~mL})$. The white solid (APSG) was then collected and dried under vacuum at $60{ }^{\circ} \mathrm{C}$ (yield: $2.9 \mathrm{~g}$ ).

A mixture containing APSG (200 mg) and 2-methoxy1,4-naphthoquinone (MNQ, $100 \mathrm{mg}, 0.53 \mathrm{mmol}$ ) in $\mathrm{MeOH}(7.0 \mathrm{~mL})$ was heated under reflux for $16 \mathrm{~h}$. The orange solid product was filtered off, washed with EtOH until the washing was colorless and dried under vacuum (yield of 2-(3-aminopropyl silica gel)-1,4-naphthoquinone, APSGNQ: $182 \mathrm{mg}$ ), Scheme 1a. For the purpose of comparison, the ungrafted 2-(3-butylamino)-1,4naphthoquinone (ABNQ) was also synthesized from MNQ and butylamine (Scheme $1 \mathrm{~b}){ }^{26}$ 
(a)

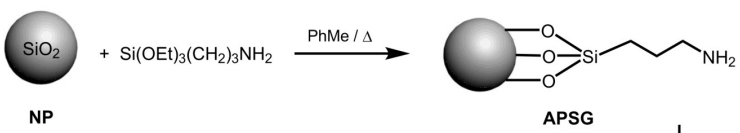

NP

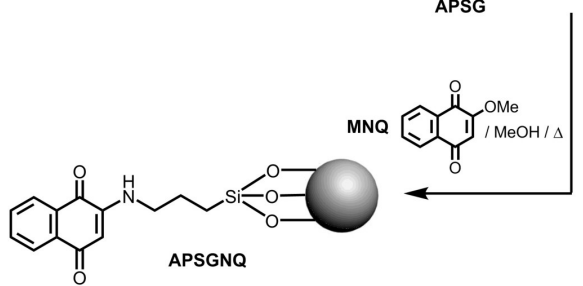

(b)

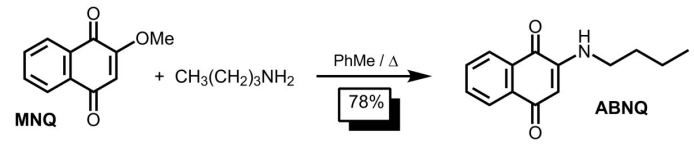

Scheme 1. (a) Functionalization of the NPs surface with amino groups, ${ }^{2}$ followed by reaction of APSG with 2-methoxy-1,4-naphthoquinone (MNQ); (b) reaction of MNQ with butylamine to give $\mathrm{ABNQ}$, for the purpose of comparison. APSG and APSGNQ pictures are idealized models, i.e., formation of oligomers and polymers on the silica surface is not shown for the sake of clarity.

\section{Results and Discussion}

\section{FTIR spectra}

FTIR analyses of the previously heated NPs, APSG and of the final product APSGNQ (Scheme 1) were carried out at room temperature (Figure S1, Supplemantary Information - SI). Diffuse reflectance FTIR (DRIFT) spectra were obtained after heating at $180^{\circ} \mathrm{C}$ under $\mathrm{N}_{2}$ for $20 \mathrm{~min}$ (Figure 1), in order to remove all adsorbed water from the surface. The presence of water was evidenced in the spectra obtained at $100^{\circ}$ and $150^{\circ} \mathrm{C}$.

The bands at about 1097 and $804 \mathrm{~cm}^{-1}$ refer to asymmetric and symmetric $\mathrm{Si}-\mathrm{O}-\mathrm{Si}$ stretches, respectively, which dominate the spectra of all samples (Figure S1, SI). The main differences between the spectra of NPs and APSG (Figures 1a and b, respectively) were due to the bands attributed to $v(\mathrm{C}-\mathrm{H})$ stretches, clearly identified at 2975 and $2879 \mathrm{~cm}^{-1}$, and weak bands due to $v(\mathrm{~N}-\mathrm{H})$ stretches at 3352 and $3294 \mathrm{~cm}^{-1}$, associated to the presence of the aminopropyl group. Incorporation of the naphthoquinone to APSG (Figure 1c) resulted in the appearance, in the spectrum of APSGNQ, of bands at 3380,1682 and $1607 \mathrm{~cm}^{-1}$ assigned to $v(\mathrm{~N}-\mathrm{H}), v(\mathrm{C}=\mathrm{O})$ and $v(\mathrm{C}=\mathrm{C})$ stretches, respectively; the $\mathrm{v}(\mathrm{N}-\mathrm{H})$ band could only be observed upon heating the sample at $180{ }^{\circ} \mathrm{C}$, due to the presence of the stretching vibration band of adsorbed water, $v(\mathrm{O}-\mathrm{H})$, observed at $3444 \mathrm{~cm}^{-1}$. As expected the infrared spectra of APSGNQ and of a pure sample of ABNQ are very similar (Figure S2, SI) thus confirming the anchoring of the naphthoquinone moiety.
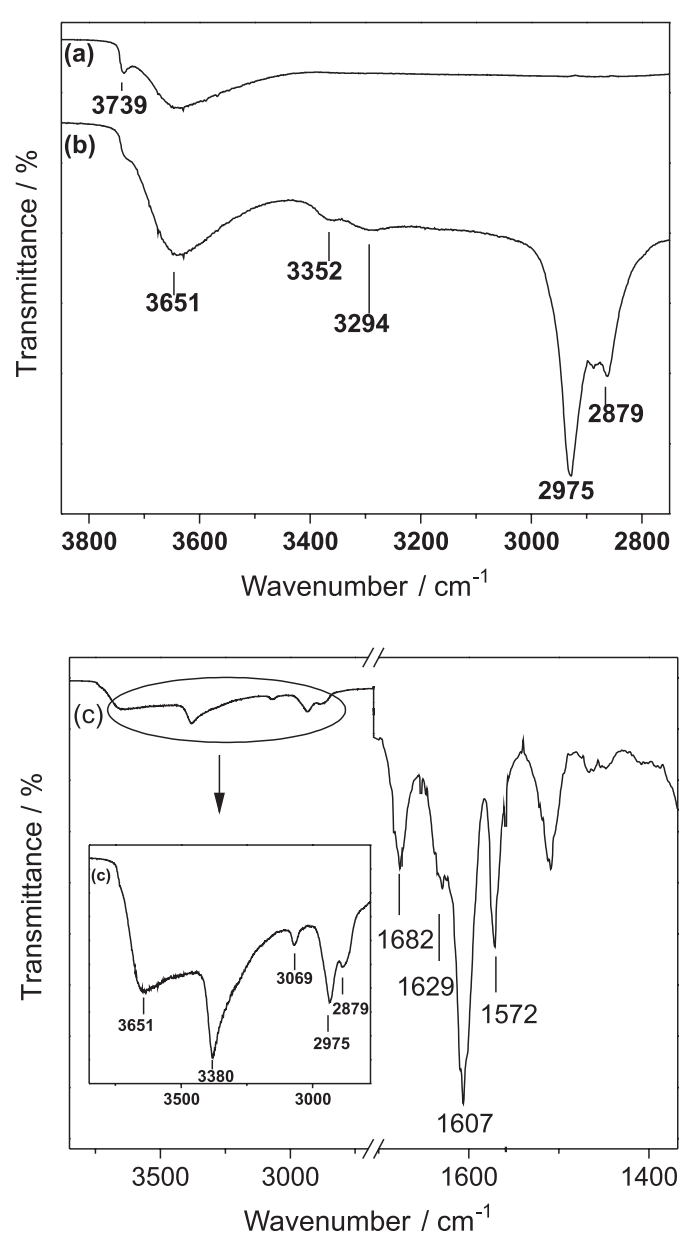

Figure 1. DRIFT spectra of (a) NPs, (b) APSG and (c) APSGNQ. The samples were heated at $180{ }^{\circ} \mathrm{C}$ under $\mathrm{N}_{2}$ for $20 \mathrm{~min}$ prior to spectra collection.

\section{Elemental and thermogravimetric analyses}

The nitrogen contents in the APSG and APSGNQ samples were assessed from elemental analysis and in the first case also by argentometry, ${ }^{30}$ and the results are summarized in Table 1. Elemental analysis ${ }^{31}$ and argentometry of APSG gave respectively 0.61 and $0.59 \mathrm{mmol} \mathrm{g}^{-1}$ of amine groups on the surface. Considering that the $\mathrm{C} / \mathrm{N}$ obtained was the expected one, it can be assumed that no silicon carbide was produced under the conditions employed for the elemental analysis (inert gas flow). Furthermore the elemental analysis of APSGNQ indicates that not all the amine groups have reacted with the naphthoquinone (see UV-Vis and NMR results below).

Thermogravimetric analysis was used to assess the thermal stability of APSG and APSGNQ (Figure 2). There is an initial weight loss that can be assigned to the release of adsorbed water from APSG and APSGNQ, respectively. Subsequently, there is a weight loss for both samples over the approximate temperature range of $200-600^{\circ} \mathrm{C}$ that can 
Table 1. Results of elemental analyses and calculated amine concentration in APSG and APSGNQ samples

\begin{tabular}{|c|c|c|c|c|}
\hline \multirow[t]{2}{*}{ Sample } & \multicolumn{3}{|c|}{ Elemental content } & \multirow{2}{*}{$\begin{array}{c}\text { Amine } \\
\text { concentration } \\
\left(\mathrm{mmol} \mathrm{g}^{-1}\right)^{a}\end{array}$} \\
\hline & $\mathrm{C} \%$ & $\mathrm{~N} \%$ & $\begin{array}{c}\mathrm{C} / \mathrm{N} \\
\text { (expected) }\end{array}$ & \\
\hline APSG & 2.19 & 0.85 & $3.00(3.00)$ & 0.59 \\
\hline APSGNQ & 6.01 & 0.64 & $10.8(13.00)$ & N. D. ${ }^{b}$ \\
\hline
\end{tabular}

${ }^{a}$ Argentometry; ${ }^{b}$ not determined.

be assigned to both decomposition of the aminopropyl groups and thermal condensation of residual silanol groups. The total weight loss at $1100{ }^{\circ} \mathrm{C}$ was $11.0,19.0$ and $17.0 \%$ for the silica NPs, APSG and APSGNQ samples respectively.

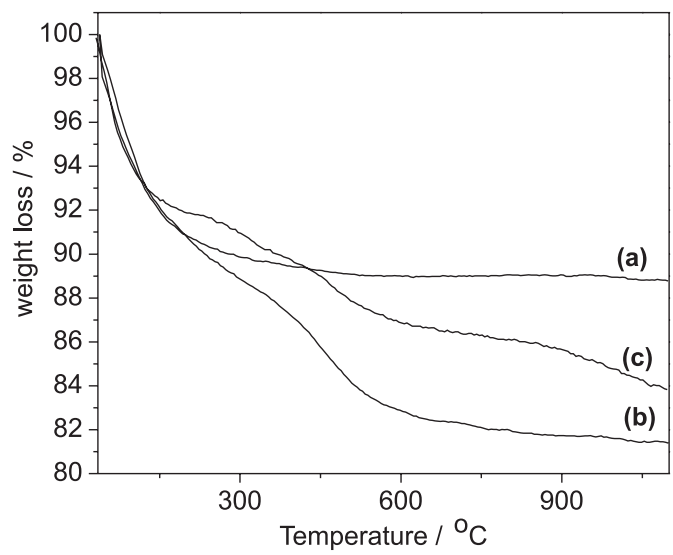

Figure 2. Thermogravimetric curves of (a) silica NPs, (b) APSG and (c) APSGNQ.

\section{$U V$-Vis spectra}

Quantification of the naphthoquinone content in APSGNQ was carried out by UV-Vis spectroscopy measurements. Both APSGNQ and ungrafted ABNQ were soluble in common organic solvents and exhibited very similar spectra. The spectra of APSGNQ (1.2 mg per $10 \mathrm{~mL}$ of dmso) and of ABNQ in the same solvent $\left(2.86 \times 10^{-5} \mathrm{~mol} \mathrm{~L}^{-1}\right.$, Figure 3$)$ showed a band around $334 \mathrm{~nm}$ corresponding to the aromatic system $\pi-\pi^{*}$ transitions, and a broad band in the visible region around $457 \mathrm{~nm}$ due to the quinone carbonyls $\mathrm{n}-\pi^{*}$ transition..$^{32}$ The naphthoquinone concentration in the APSGNQ solution was determined using the absorption band in the visible region, which resulted in $0.56 \mathrm{mmol}$ of incorporated naphthoquinone per gram of APSGNQ. This result is in accordance with the elemental analyses and suggests that about $8 \%$ of the surface propylamine remained unreacted in APSGNQ. Thus, UV-Vis spectroscopy has been a valuable and quick method to determine the naphthoquinone content in this material.
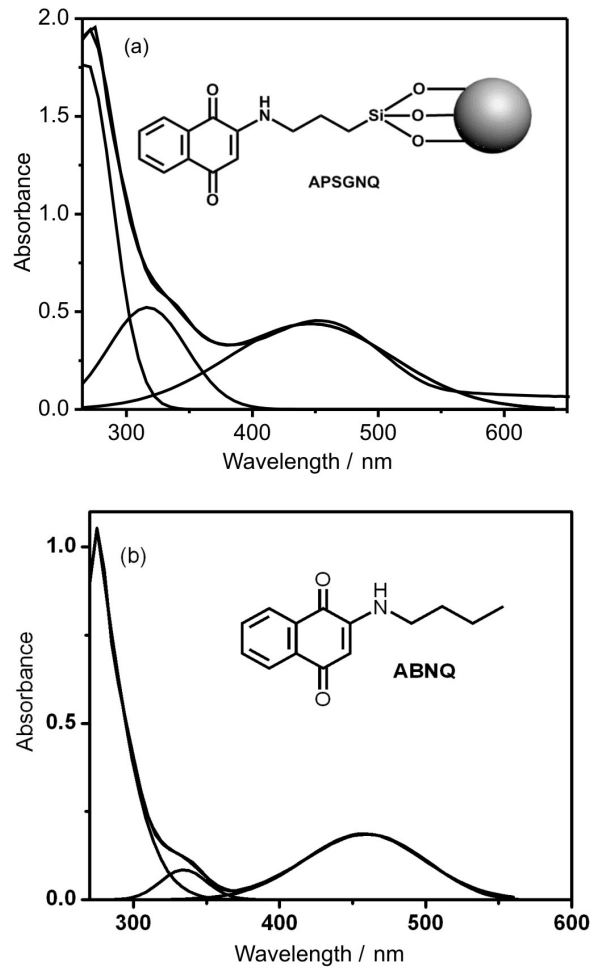

Figure 3. UV-Vis spectra of (a) APSGNQ in dmso (12 mg in $10 \mathrm{~mL}$ of dmso) and (b) ABNQ $\left(1.97 \times 10^{-4} \mathrm{~mol} \mathrm{~L}^{-1}\right)$.

Figure 4 shows the ${ }^{29} \mathrm{Si}$ CPMAS spectra obtained for the NPs, APSG and APSGNQ samples, whereas the ${ }^{13} \mathrm{C}$ CPMAS spectra obtained for APSG, APSGNQ and 2-methoxy-1,4-naphthoquinone are depicted in Figure 5. With the pulse sequence employed (see Experimental), the ${ }^{29} \mathrm{Si}$ and ${ }^{13} \mathrm{C}$ signals are related to the magnitude of the dipolar interaction with protons, which depends on geometrical factors, namely, the ${ }^{1} \mathrm{H}-{ }^{29} \mathrm{Si}$ and ${ }^{1} \mathrm{H}-{ }^{13} \mathrm{C}$ internuclear distances, respectively, by factors $r_{\mathrm{SiH}}^{-3}$ and $r_{\mathrm{CH}}^{-3}$. In this way $\mathrm{Q}^{4}, \mathrm{Q}^{3}$ and $\mathrm{Q}^{2}{ }^{29} \mathrm{Si}$ sites are observed. Similarly, in the ${ }^{13} \mathrm{C}$ NMR spectra, protonated and non-protonated carbon atoms can be observed..$^{33}$

In the ${ }^{29} \mathrm{Si}$ CPMAS spectrum of NPs (Figure $4 \mathrm{a}$ ), signals due to $\mathrm{SiO}_{2}(\mathrm{OH})_{2}\left(\mathrm{Q}^{2}\right.$ sites $)$ at $-84 \mathrm{ppm}, \mathrm{SiO}_{3}-\mathrm{OH}$ $\left(\mathrm{Q}^{3}\right.$ sites $)$ at $-96 \mathrm{ppm}$ and $\mathrm{SiO}_{4}\left(\mathrm{Q}^{4}\right.$ sites $)$ at $-111 \mathrm{ppm}$ were observed. The spectra of APSG and APSGNQ (Figures $4 \mathrm{~b}$ and $\mathrm{c}$, respectively) indicated the absence of the $\mathrm{Q}^{2}$ sites and showed the presence of $\mathrm{T}^{\mathrm{n}}$ sites: in the -50 to $-60 \mathrm{ppm}$ range $\left(\mathrm{T}^{2}\right.$ site, $\left.\mathrm{C}-\mathrm{Si}(\mathrm{OSi})_{2} \mathrm{OH}\right)$, and -60 to $-75 \mathrm{ppm}\left(\mathrm{T}^{3}\right.$ site, $\left.\mathrm{C}-\mathrm{Si}(\mathrm{OSi})_{3}\right)$, in addition to the $\mathrm{Q}^{3}$ and $\mathrm{Q}^{4}$ sites, at -98 and $-107 \mathrm{ppm}$, respectively, thus confirming the presence of the aminopropyl group covalently bound to the silica NPs. ${ }^{34}$ The relative increase in the intensity of peak $\mathrm{Q}^{4}$ in the spectrum of APSG in comparison with that of NPs (Figures $4 \mathrm{~b}$ and $\mathrm{c}$, respectively) indicates that further condensation 

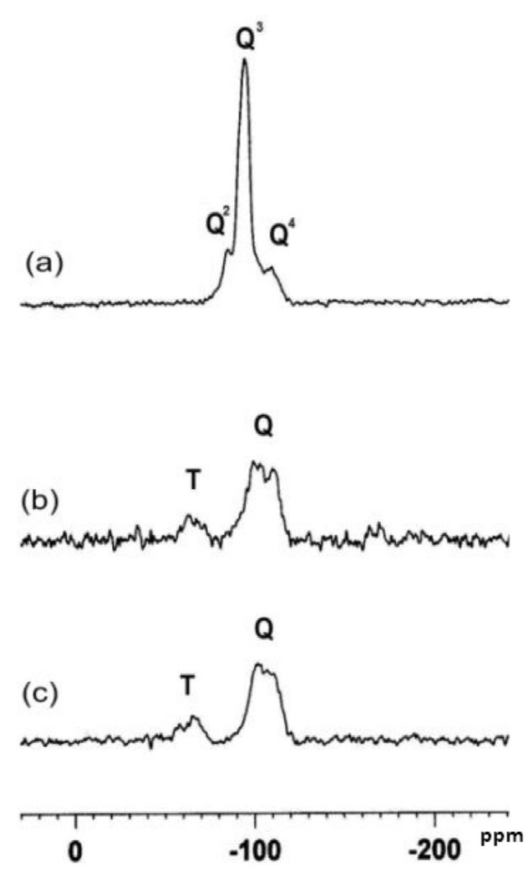

Figure 4. ${ }^{29} \mathrm{Si}$ CPMAS NMR spectra of (a) NPs, (b) APSG and (c) APSGNQ samples.
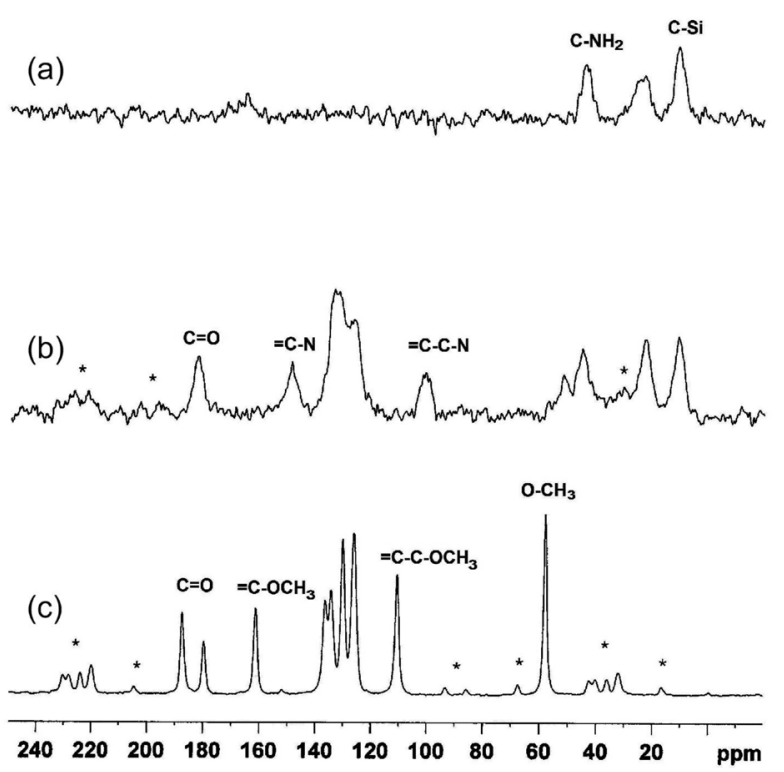

Figure 5. ${ }^{13} \mathrm{C}$ CPMAS NMR spectra of (a) APSG, (b) APSGNQ and (c) 2-methoxy-1,4-naphthoquinone (MNQ). (*) Spinning sidebands.

has also occurred between unreacted hydroxy groups of silane molecules bound to the silica surface and hydrolyzed ethoxy groups from APTS or from bound $-\mathrm{OSi}(\mathrm{OEt})_{\times}\left(\mathrm{CH}_{2}\right)_{3} \mathrm{NH}_{2}$, resulting in oligomerized and polymerized layers, as described previously. ${ }^{29}$

The concentration of functional groups in APSG and APSGNQ was measured from the relative intensities of $\mathrm{T}^{\mathrm{n}}$ and $\mathrm{Q}^{\mathrm{n}}$ silicon groups observed by ${ }^{29} \mathrm{Si}$ MAS NMR under direct polarization and high power proton decoupling. The results indicated in both cases that about 3 molar $\%$ of $\mathrm{Si}-\mathrm{O}$ sites corresponded to $\mathrm{T}^{\mathrm{n}}$ sites, i.e., that $3 \%$ of silicon atoms were bound to aminopropyl groups. This value, which is lower than those given by elemental analysis and argentometry (see above), is probably obtained because the low aminopropyl content of both materials makes quantitative analysis difficult.

${ }^{13} \mathrm{C}$ CPMAS spectra of APSG and APSGNQ (Figures 5a and b) confirmed the results obtained from the ${ }^{29} \mathrm{Si}$ CPMAS NMR spectra. The carbon chemical shifts of $\underline{\mathrm{CH}}_{2}-\mathrm{NH}_{2}$ (44 ppm), $\mathrm{C}-\underline{\mathrm{C}} \mathrm{H}_{2}-\mathrm{C}$ (23 ppm) and $\underline{\mathrm{CH}}_{2}-\mathrm{Si}$ $(11 \mathrm{ppm})$ in the spectrum of APSG are similar to those obtained by Rahman et al. ${ }^{35}$ The spectrum of APSGNQ exhibits the resonances of APSG together with a peak due to $\mathrm{CH}_{2}-\mathrm{NH}$-naphthoquinone (52 ppm) and those attributed to the naphthoquinone carbon atoms, thus confirming the presence of unreacted amine groups. The spectrum of 2-methoxy-1,4-naphthoquinone (MNQ) was included for comparison (Figure 5c) and presented well resolved signals, evidencing the crystalline nature of this compound. Displacement of the methoxy group by the surface amine of APSG was confirmed by the absence, in the spectrum of APSGNQ, of the peak associated to the MNQ O- $\mathrm{CH}_{3}$ carbon, at $58 \mathrm{ppm}$, besides the clear shift of the $\underline{\mathrm{C}}_{\mathrm{ar}}-\mathrm{O}$ signal at $161 \mathrm{ppm}$, in the spectrum of MNQ, to $149 \mathrm{ppm}$ in the spectrum of APSGNQ. Furthermore, shifts of the signals attributed to the $\underline{\mathrm{C}}=\mathrm{O}$ groups (at 185 and $180 \mathrm{ppm}$ ) and $\underline{\underline{C}}_{\mathrm{ar}}$ (between 120 and $140 \mathrm{ppm}$ ) are also observed. We conclude, therefore, that the incorporation of 1,4-naphthoquinones onto modified silica NPs is easily carried out via the same route used for the synthesis of amino-substituted 1,4-naphthoquinones. ${ }^{26,36}$ The fact that some amine groups remained unreacted might be associated to the oligomerization or polymerization of silane molecules bound to the silica surface (see above NMR discussion $)^{29}$ making it difficult for the amine to react with the naphthoquinone.

\section{Conclusions}

Our work has demonstrated that the reaction of aminopropylsilicalgel NPs with labile 2-methoxy-1,4naphthoquinones is a good route to silica NPs containing bound amino-naphthoquinones. The material was fully characterized by a combination of techniques that established that the 1,4-naphthoquinone is covalently bound to the silica NPs. Even though the methodology proved itself efficient, further investigation is necessary to produce material with larger amounts of aminonaphthoquinone groups on the silica surface. Considering that modification of the 1,4and 1,2-naphthoquinone nuclei with amines has resulted in increased cytotoxic activity ${ }^{20}$ and that surface modified 
NPs can be efficiently endocytosed in vitro by a variety of mammalian cells including cancer and non cancer cells, ${ }^{13}$ it is possible that the binding of naphthoquinone onto NPs may help to increase the concentration of this compound inside the cells and therefore its cytotoxicity.

\section{Supplementary Information}

Supplementary information associated with this paper contains the FTIR spectra of the synthesized materials. It is available free of charge at http://jbcs.sbq.org.br as PDF file.

\section{Acknowledgements}

Authors gratefully acknowledge FAPERJ (Primeiros Projetos and Jovens Emergentes), Pronex-FAPERJ (grant number E-26/171.512/2006) and CAPES (G. Q. S. fellowship) for financial support. M. D. V and C. M. R. are recipients of CNPq research fellowships. We thank Dr. A. Faro (IQ-UFRJ, Brazil) for the DRIFT spectra and Dr. Ana Maria Rangel de Figueiredo Teixeira and Wildson Vieira Cerqueira (IQ-UFF) for the TGA analyses.

\section{References}

1. Iler, R. K.; Colloids Surf., A 1998, 142, 59.

2. Cauvel, A.; Renard, G.; Brunel, D.; J. Org. Chem. 1997, 62, 749.

3. Alauzun, J.; Mehdi, A.; Reye, C.; Corriu, R.; New J. Chem. 2007, 31, 911; Luts, T.; Suprun, W.; Hofman, D.; Klepel, O.; Papp, H.; J. Mol. Catal. A: Chem. 2007, 261, 16.

4. Jal, P. K.; Patel, S.; Mishra, B. K.; Talanta 2004, 62, 1005.

5. Margelefsky, E. L.; Zeidan, R. K.; Dufaud, V.; Davis, M. E.; J. Am. Chem. Soc. 2007, 129, 13691.

6. Okada, K.; Shimai, A.; Takei, T.; Hayashi, S.; Yasumori, A.; Mackenzie, K. J. D.; Microporous Mesoporous Mater. 1998, 21, 289.

7. Hu, A. H.; Liu, T. Y.; Huang, H. Y.; Liu, D. M.; Chen, S. Y.; Langmuir 2008, 24, 239; Yang, J.; Lee, J.; Kang, J.; Lee, K.; Suh, J. S.; Yoon, H. G.; Huh, Y. M.; Haam, S.; Langmuir 2008, 24, 3417; Yagüe, C.; Moros, M.; Grazú, V.; Arruebo, M.; Santamaría, J.; Chem. Eng. J. (Amsterdam, Neth.) 2008, 137, 45; Ma, H.; Zhou, J.; Caruntu, D.; Yu, M.; Chen, J. F.; Connor, C. J. O.; Zhou, W. L.; J. Appl. Phys. 2008, 103, 07A320; Kim, S.; Ohulchanskyy, T. Y.; Pudavar, H. E.; Pandey, R.; K.; Prasad, P. N.; J. Am. Chem. Soc. 2007, 129, 2669.

8. Silva, L. B.; Baptista, P.; Raniero, L.; Doria, G.; Martins, R.; Fortunato, E.; Sens. Actuators, B 2008, 132, 508; Khan, R.; Kaushik, A.; Solanki, P. R.; Ansari, A. A.; Pandey, M. K.; Malhotra, B. D.; Anal. Chim. Acta 2008, 616, 207.

9. Law, W. C.; Yong, K. T.; Roy, I.; Xu, G.; Ding, H.; Bergey, E. J.; Zeng, H.; Prasad, P. N.; J. Phys. Chem. C 2008, 112, 7972.
10. Wei, H.; Zhou, L.; Li, J.; Liu, J.; Wang, E.; J. Colloid Interface Sci. 2008, 321, 310; Wang, J.; Liu, G.; Wu, H.; Lin, Y.; Anal. Chim. Acta 2008, 610, 112.

11. Liong, M.; Lu, J.; Kovochich, M.; Xia, T.; Ruehm, S. G.; Nel, A. E.; Tamanoi, F.; Zink, J. I.; ACS Nano 2008, 2, 889.

12. Slowing, I. I.; Wu, C. W; Vivero-Escoto, J. L.; Lin, V. S. Y.; Small 2009, 5, 57; Slowing, I. I.; Vivero-Escoto, J. L.; Lin, V. S. Y.; J. Mater. Chem. 2010, 20, 7924.

13. Slowing, I. I.; Vivero-Escoto, J. L.; Wu, C. W.; Lin, V. S. Y.; $A d v$. Drug Delivery Rev. 2008, 60, 1278.

14. He, X.; Nie, H.; Wang, K.; Tan, W.; Wu, X.; Zhang, P.; Anal. Chem. 2008, 80, 9597; Burns, A. A.; Vider, J.; Ow, H.; Herz, E.; Medina, O. P.; Baumgart, M.; Larson, S. M.; Wiesner, U.; Bradbury, M.; Nano Lett. 2009, 9, 442.

15. Francisco, A. I.; Vargas, M. D.; Fragoso, T. P.; Carneiro, J. W. M.; Casellato, A.; Silva, F. C.; Ferreira, V. F.; Barbosa, J. P.; Pessoa, C.; Costa-Lotufo, L. V.; Marinho Filho, J. D. B.; Moraes, M. O.; Mangrich, A. S.; J. Braz. Chem. Soc. 2010, 21, 1293 and references therein.

16. Gafner, S.; Wolfender, J. -L.; Nianga, M.; Stoeckli-Evans, H.; Hostettman, K.; Phytochemistry 1996, 42, 1315.

17. Kayser, O.; Kiderlen, A. F.; Laatsch, H.; Croft, S.; Acta Tropica 2000, 77, 307; Baramee, A.; Coppin, A.; Mortuaire, M.; Pelinski, L.; Tomavo, S.; Brocard, J.; Bioorg. Med. Chem. 2006, 14, 1294; Dalgliesh, C. E.; J. Am. Chem. Soc. 1949, 71, 1697; Leffer, M. T.; Hathaway, R. J.; J. Am. Chem. Soc. 1948, 70, 3222; Moura, K. C. G.; Emery, F. S.; Neves-Pinto, C.; Pinto, M. C. F. R.; Dantas, A. P.; Salomão, K.; Castro, S. L.; Pinto, A. V.; J. Braz. Chem. Soc. 2001, 12, 325; Silva Júnior, E. N.; Moura, M. A. B. S.; Pinto, A. V.; Pinto, M. C. F. R.; Souza, M. C. B. V.; Araújo, A. J.; Pessoa, C.; Costa-Lotufo, L.V.; Montenegro, R. C.; Moraes, M. O.; Ferreira, V. F.; Goulart, M. O. F.; J. Braz. Chem. Soc. 2009, 20, 635; Silva Junior, E. N.; Menna-Barreto, R. F. S.; Pinto, M. C. F. R.; Silva, E. S. F.; Teixeira, D. V.; de Souza, M. C. B. V.; Simone, C. A.; Castro, S. L.; Ferreira, V. F.; Pinto, A. V.; Eur. J. Med. Chem. 2008, 43, 1774; Silva Júnior, J. N.; Souza, M. C. B. V.; Fernandes, M. C.; Menna-Barreto, R. F. S.; Pinto, M. C. F. R.; Lopes, F. A.; Simone, C. A.; Pinto, A. V.; Ferreira, V. F.; Castro, S. L.; Bioorg. Med. Chem. 2008, 16, 5030; Jorqueira, A.; Gouvêa, R. M.; Ferreira, V. F.; Silva, M. N.; Souza, M. C. B. V.; Zuma, A. A.; Cavalvanti, D. F. B.; Araújo, H. P.; Santos, D. O.; Bourguignon, S. C.; Parasitol. Res. 2006, 99, 429; Pinto, A. V.; Silva, R. S. F.; Simone, C. A.; Castro, S. L.; Smalta, V. R.; Santos, G. L.; Costa, E.; Trindade, U. L. T.; Teixeira, D. V.; Pinto, M. C. F. R.; Eur. J. Med. Chem. 2006, 41, 526; Pinto, A. V.; Castro, S. L.; Menna-Barreto, R. F. S.; Dias, J. A. M.; Soares, M. J.; J. Antimicrob. Chemother. 2005, 56, 1034.

18. Silva, A. J. M.; Netto, C. D.; Pacienza-Lima, W.; Torres-Santos, E. C.; Rossi-Bergmann, B.; Maurel, S.; Valentin, A.; Costa, P. R. R.; J. Braz. Chem. Soc. 2009, 20, 176; Pinto, A. V.; Goulart, M. O. F.; Andrade-Neto, V. F.; Silva, J. F.; Silva, M. J.; Pinto, M. D.; 
Zalis, M. G.; Carvalho, L. H.; Krettli, A. U.; Bioorg. Med. Chem. Lett. 2004, 14, 1145.

19. Subramanian, S.; Ferreira, M. M. C.; Trsic, M.; Struct. Chem. 1998, 9, 47; Siripong, P.; Yahyafai, J.; Shimizu, K.; Ichikawa, S.; Asai, T.; Kanokmedakul, K.; Ruchirawat, S.; Oku, N.; Biol. Pharm. Bull. 2006, 29, 2279; Chenna, P. H. D.; Benedetti-Doctorovich, V.; Baggio, R. F.; Garland, M. T.; Burton, G.; J. Med. Chem. 2001, 44, 2486; Ravelo, A. G.; Braun, A. E.; Orellana, H. C.; Sacau, E. P.; Siverio, D. M.; Curr. Top. Med. Chem. (Sharjah, United Arab Emirates) 2004, 4, 241.

20. Vargas, M. D.; Pinto, A. C.; Echevarria, A.; Esteves-Souza, A.; Camara, C. A.; Cunha, A. C.; Torres, J. C.; Lima, E. L. S.; J. Braz. Chem. Soc. 2006, 17, 439; Esteves-Souza, A.; Figueiredo, D. V.; Câmara, C. A.; Vargas, M. D.; Pinto, A. C.; Echevarria, A.; Braz. J. Med. Biol. Res. 2007, 40, 1399; Cunha, A. S.; Vargas, M. D.; Gattassi, C. R.; Pinto, A. C.; Camara, C. A.; Esteves-Souza, A.; Lima, E. L. S.; Oncol. Rep. 2008, 20, 225; Silva Júnior, E. N.; de Deus, C. F.; Cavalcanti, B. C.; Pessoa, C.; Costa-Lotufo, L. V.; Montenegro, R. C.; de Moraes, M. O.; Pinto, M. C. F. R.; Simone, C. A.; Ferreira, V. F.; Goulart, M. O. F.; Andrade, C. K. Z.; Pinto, A. V.; J. Med. Chem. 2010, 53, 504.

21. Ferreira, S. B.; Silva, F. C.; Bezerra, F. A. F. M.; Lourenço, M. C. S.; Kaiser, C. R.; Pinto, A. C.; Ferreira, V. F.; Arch. Pharm. (Weinheim, Germany) 2010, 343, 81.

22. Ribeiro, K. A. L.; Carvalho, C. M.; Molina, M. T.; Lima, E. P.; López-Montero, E.; Reys, J. R. M.; Oliveira, M. B. F.; Pinto, A. V.; Santana, A. E. G.; Goulart, M. O. F.; Acta Tropica 2009, 44.

23. Silva Junior, E. N.; de Souza, M. C. B. V.; Pinto, A. V.; Pinto, M. C. F. R.; Goulart, M. O. F.; Barros, F. W. A.; Pessoa, C.; CostaLotufo, L. V.; Montenegro, R. C.; Moraes, M. O.; Ferreira, V. F.; Bioorg. Med. Chem. 2007, 15, 7035; Fry, F. H.; Jacob, C.; Curr. Pharm. Des. 2006, 12, 4479; Asche, C.; Mini-Rev. Med. Chem. 2005, 5, 449; Hassani, M.; Cai, W.; Holley, D. C.; Lineswala, J. P.; Maharjan, B. R.; Ebrahimian, G. R.; Seradj, H.; Stocksdale, M. G.; Mohammadi, F.; Marvin, C. C.; Gerdes, J. M.; Beall, H. D.; Behforouz, M.; J. Med. Chem. 2005, 48, 7733; Lee, J. H.; Cheong, J. H.; Park, Y. M.; Choi, Y. H.; Pharmacol. Res. 2005, 51, 553; Liu, K. K. C.; Li, J.; Sakya, S.; Mini-Rev. Med. Chem. 2004, 4, 1105; Kongkathip, N.; Siripong, P.; Sangma, C.; Luangkamin, S.; Niyomdecha, M.; Pattanapa, S.; Piyaviriyalgul, S.; Kongsaeree, P.; Bioorg. Med. Chem. 2003, 11, 3179.

24. Neves, A. P.; Barbosa, C. C.; Greco, S. J.; Vargas, M. D.; Visentin, L. C.; Pinheiro, C. B.; Mangrich, A. S.; Barbosa, J. P.; Costa, G. L.; J. Braz. Chem. Soc. 2009, 20, 712; Tapia, R. A.; Cantuarias,
L.; Cuéllar, M.; Villena, J.; J. Braz. Chem. Soc. 2009, 20, 999; Francisco, A. I.; Casellato, A.; Neves, A. P.; Carneiro, J. W. M.; Vargas, M, D.; Visentin, L. C.; Magalhães, A.; Câmara, C. A.; Pessoa, C.; Costa-Lotufo, L. V.; Marinho Filho, J. D. B.; Moraes, M. O.; J. Braz. Chem. Soc. 2009, 21, 169.

25. Fieser, L. F.; Martin, E. L.; Org. Synth. 1955, Coll. Vol. 3, 465.

26. Vargas, M. D.; Camara, C. A.; Pinto, A. C.; Rosa, M. A.; Tetrahedron 2001, 57, 9569.

27. Pedroso, M. A. S.; Dias, M. L.; Azuma, C.; San Gil, R. A. S.; Mothé, C. G.; Colloid Polym. Sci. 2003, 281, 19.

28. Zapilko, C.; Widenmeyer, M.; Nagl, I.; Estler, F.; Anwander, R.; Sieber, G. R.; Groeger, O.; Engelhardt, G.; J. Am. Chem. Soc. 2006, 128, 16266; Kao, H. M.; Liao, C. H.; Palani, A.; Liao, Y. C.; Microporous Mesoporous Mater. 2008, 113, 212.

29. Shimizu, I.; Yoshino, A.; Okabayashi, H.; Nishio.; E.; O'Connor, C. J.; J. Chem. Soc., Faraday Trans. 1997, 93, 1971.

30. Yokoi, T.; Yoshitake, T.; Yamada, T.; Kubota, Y.; Tatsumi, T.; J. Mater. Chem. 2006, 16, 1125.

31. Yoshino, A.; Okabayashi, H.; Shimizu, I.; O'Connor, C. J.; Colloid. Polym. Sci. 1997, 275, 672; Guo, Z. X.; Yu, J.; J. Mater. Chem. 2002, 12, 468; Yokoi, T.; Yoshitake, H.; Tatsumi, T.; J. Mater. Chem. 2004, 14, 951; Luts, T.; Suprun, W.; Hofmann, D.; Klepel, O.; Papp, H.; J. Mol. Cat. A: Chem. 2007, 261, 16; Zhang, X.; Cui, W.; Han, W.; Zhang, Y.; Liu, S.; Mu, W.; Chang, Y.; Hu, R.; React. Kinet. Catal. Lett. 2009, 98, 349.

32. Reichardt, C.; Chem. Rev. 1994, 94, 2319.

33. Duer, M. J.; Solid State NMR Spectroscopy-Principles and Applications, Blackwell Science: Oxford, 2002.

34. Huh, S.; Wiench, J. W.; Yoo, J. C.; Pruski, M.; Lin, V. S. Y.; Chem. Mater. 2003, 15, 4247; Arce, V. B.; Bertolotti, S. G.; Oliveira, F. J. V. E.; Airoldi, C.; Gonzalez, M. C.; Allegretti, P. E.; Martire, D. O.; Spectrochim. Acta, Part A 2009, 73, 54.

35. Rahman, I. A.; Jafarzadeh, M.; Sipaut, C. S.; Ceram. Int. 2009, 35 , 1883.

36. Vargas, M. D.; Silva, T. M. S.; Camara, C. A.; Barbosa, T. P.; Soares, A. Z.; Cunha, L. C.; Pinto, A. C.; Bioorg. Med. Chem. Lett. 2005, 13, 193; Camara, C. A.; Silva, T. M. S.; Silva, T. G.; Barbosa, T. P.; Martins, R. M.; Vargas, M. D.; Pinto, A. C.; An. Acad. Bras. Ciênc. 2008, 80, 329.

Submitted: July 19, 2010 Published online: February 10, 2011

FAPESP has sponsored the publication of this article. 


\section{Modified Silica Nanoparticles with an Aminonaphthoquinone}

\section{Gleiciani Q. Silveira, ${ }^{a}$ Célia M. Ronconi, ${ }^{* a}$ Maria D. Vargas, ${ }^{*, a}$ Rosane A. S. San Gil ${ }^{b}$ and Alvicler Magalhães ${ }^{c, d}$}

${ }^{a}$ Instituto de Química, Universidade Federal Fluminense, Campus do Valonguinho, Centro, 24020-150 Niterói-RJ, Brazil

${ }^{b}$ Instituto de Química, Universidade Federal do Rio de Janeiro, Ilha do Fundão, 21945-970 Rio de Janeiro-RJ, Brazil

'Instituto Oswaldo Cruz, FIOCRUZ, CP 926, 21045-900 Rio de Janeiro-RJ, Brazil

${ }^{d}$ Instituto de Química, Universidade Estadual de Campinas, CP 6154,

13084-971 Campinas-SP, Brazil

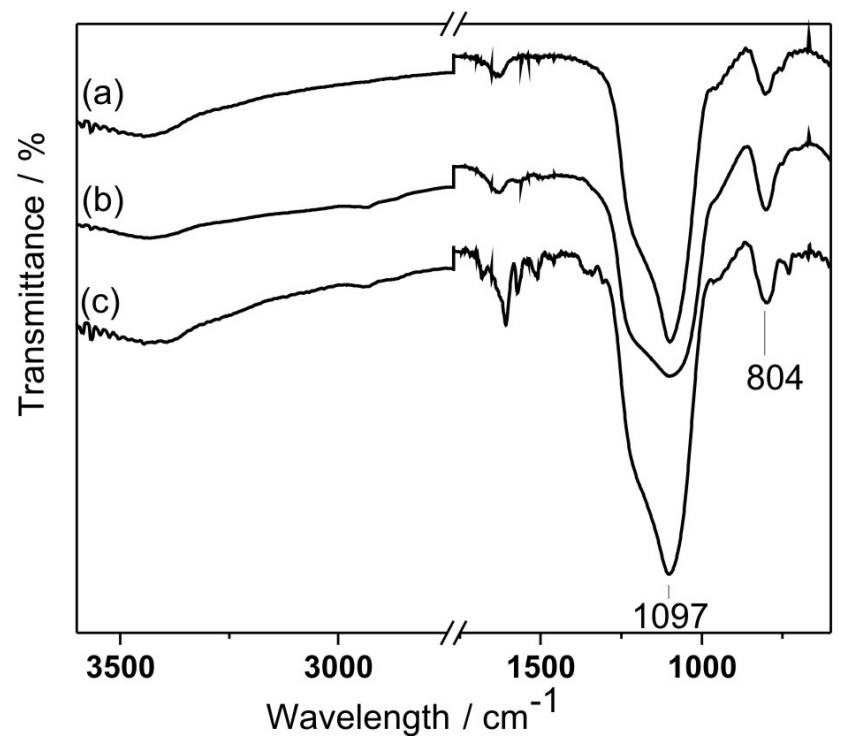

Figure S1. FTIR spectra registered at room temperature for (a) NPs, (b) APSG and (c) APSGNQ. 


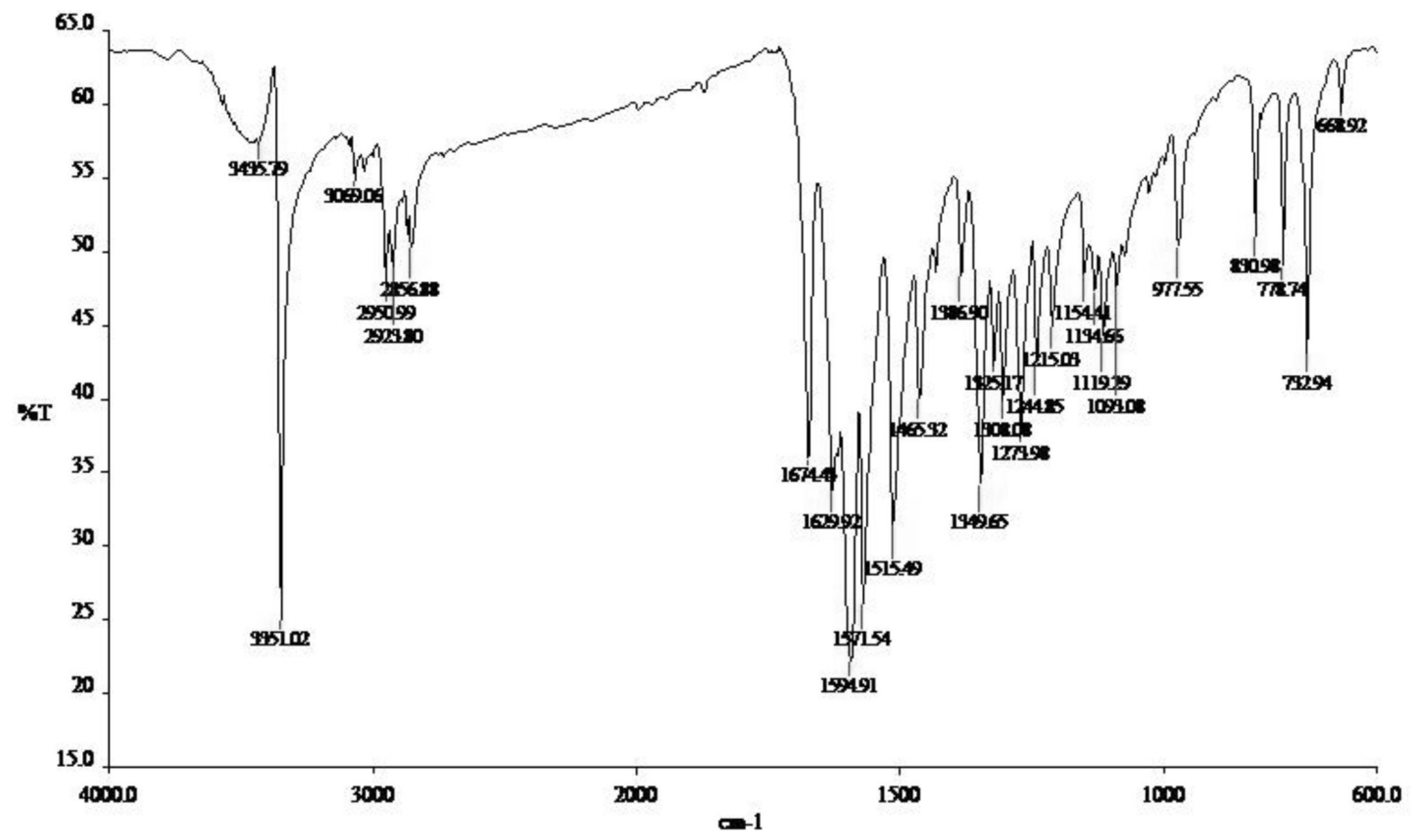

Figure S2. FTIR spectra registered at room temperature for ABNQ. 